\title{
太田川河ロにおける有機泥の挙動に関する研究 STUDY ON THE TRANSPORTATION OF ORGANIC MUD IN OHTAGAWA ESTUARY
}

\author{
富田 智 1 長戸宏樹 2 日比野忠史 ${ }^{3}$ ・西牧 均 4 ・松本英雄 5 \\ Satoshi TOMIDA, Hiroki NAGATO, Tadashi HIBINO, Hitoshi NISHIMAKI, \\ and Hideo MATSUMOTO \\ 1正会員 日本ミクニヤ懒（テ734-0015 広島市南区宇品御幸四丁目4-7） \\ 2 学生会員 広島大学大学院 工学研究科 (下739-8527 東広島市鏡山一丁目4-1) \\ 3 正会員 博 (工学) 広島大学大学院助教授 工学研究科（T739-8527 東広島市鏡山一丁目4-1） \\ 4正会員 国土交通省中国地方整備局 太田川河川工事事務所（テ730-0013 広島市中区八丁堀3-30）

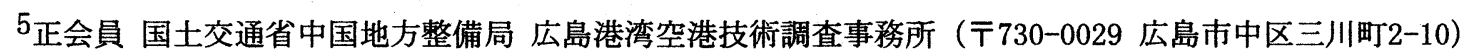

\begin{abstract}
This paper deals with a transportation of the organic matter in Ohtagawa estuary connecting to Hiroshima bay. The samples of the organic mud were obtained from the sediment trap net installed in this area. The movement of the organic mud is estimated by the variations of the trapped organic mud among the observation points in quality and quantity. The most essential ingredients were particles of 75 micrometers or less. The $\mathrm{C} / \mathrm{N}$ ratio in the sea area is different from thar in the river. It tends to rise with the soil grain fraction increasing. There was a sharp contrast between Ohtagawa River and Tenmagawa River in terms of the different source of the organic mud from September to October because of the different transportation systems between two rivers.
\end{abstract}

Key Words : Ohtagawa estuary, sediment trap, organic mud, tidal flat, POC/PON ratio

\section{1. はじめに}

内湾河口域において生物の棲息環境を決定付ける重要 な要因として微細土粒子と栄養塩によって形成される有 機泥（縣溜物質）が挙げられしる. 有機泥は周囲の環境に よって様々に形を変えるために，その挙動を明らかにす ることは極めて難しい. 特に, 河口域においては潮汐等 によって遡上する海水と河川流出水の混合, 懸濁粒子の 巻き上げや流動，底層の貧酸素化等の物理現象や有機物 の凝集・離脱, 酸化・還元等の化学的な過程が複雑に絡 み合っており, 有機泥の挙動については定量化されてい ないのが現状である.

清木ら（1985） ${ }^{1)}$ は広島湾において懸濁物質の量, 有 機物濃度を四季に渡り測定し, 濃度は夏季において最大 となり, 量は夏季に少なく, 成層崩壊に伴って秋季に集 中して増大することを示している. 河口域における物質 循環に関する研究では流れ場や水質変動に重点をおいた 現地観測やシミュレーション22，あるいは，実験室レベ ルでの巻き上げ実験了) 等が主に行われてきたが, 最近で
は, 有機泥の化学的性状や巻き上げ機構について現地調 查結果から検討するものも行われている. 山下ら (2002) ${ }^{4,5)}$ は洪水による河口域への栄盖塩の拡散機構を 懸濁物質（SS）の経時的な採取調査や䀣濁物質の凝集実 験と現地調查によって検討している. この中で, 栄養塩 がSSに凝集され海域に運搬されていることを示している.

本研究では, 流出量の異なる河川に形成された干潟堆 積物, 海水の遡上量や海域〜河川感潮域に沈降する有機 泥の質と量を把握することによって，河川〜海域間での 有機泥の挙動について述べている.

\section{2. 有機泥の挙動把握のための調査手法}

有機泥の挙動は広島湾奥部と太田川放水路，市内派川 内に設置されたセジメントトラップ（河川，海岸域 : $\phi$

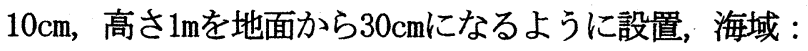
$\phi 7 \mathrm{~cm}$ ，長さ $20 \mathrm{~cm}$ 表層 $5 \mathrm{~m}$ と海底 $0 \mathrm{~cm}$ に設置）網から得ら れた沈降泥および, セジメントトラップ周辺の堆積泥の 土質特性, 含有成分と周辺水域の塩分水温の変動特性を 


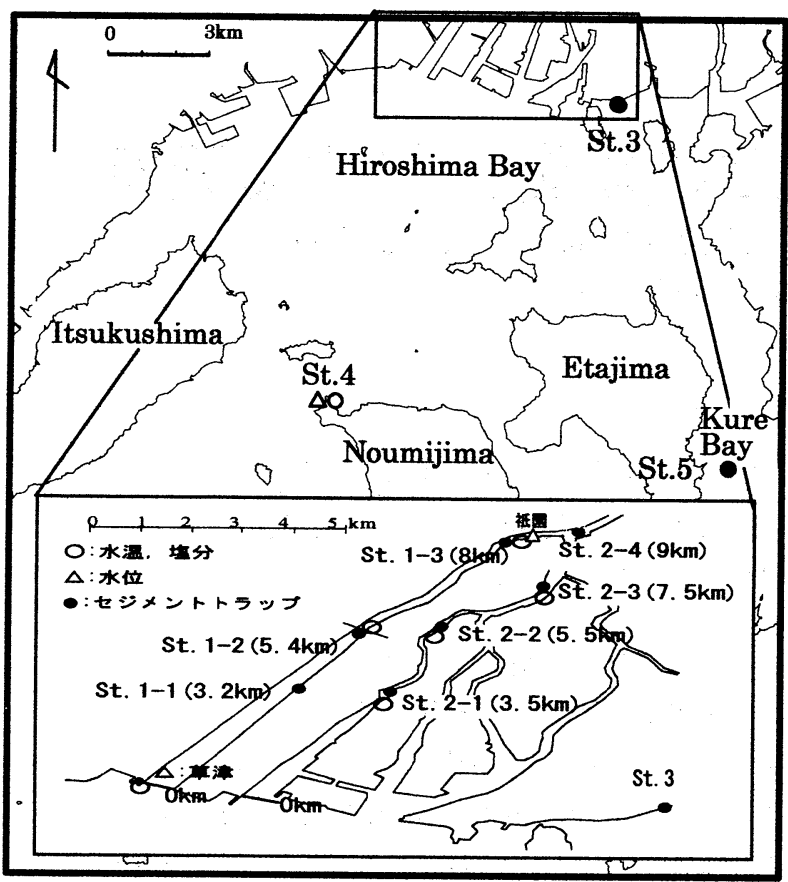

（a）広島湾・太田川感潮域での篗測点と項目

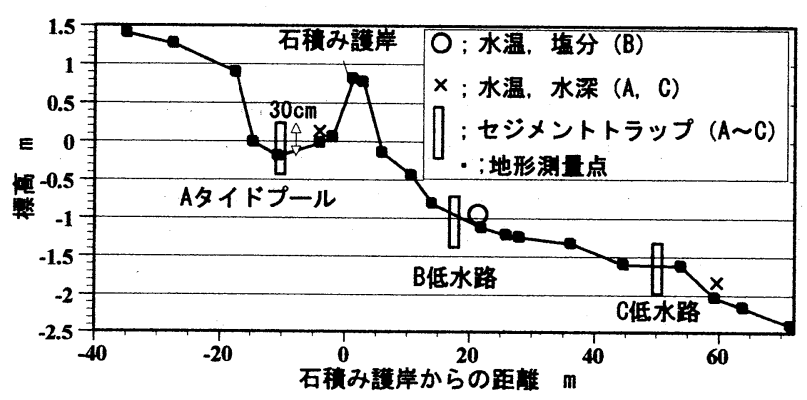

(b) St.1-2 断面の地形と観測位置

図-1 広島湾, 太田川感潮域の地形と観測概要

検討することによって把握された，図一1には太田川感 潮域の地形および本論文で使用したデータの調查地点

（St. 1 5）とセジメントトラップの設置概要が示され ている.

広島湾内では, セジメントトラップおよび水温, 水深 計が設置されている．セジメントトラップは海岸域 (St. 3，宇品）では水際（8月までは水深5mに設置）， 海域（St. 5) は海底, 海面-5mに設置された. 海底では

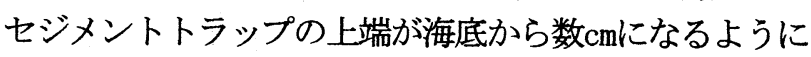
埋設, されている.

河川感潮域として，太田川放水路と市内派川を対象と した. 放水路内では，河口から約 $3.2 \mathrm{~km}$ (St. 1-1），約 5. 4km（St. 1-2 ; A C) 約 $8 \mathrm{~km}$ (St. 1-3)，市内派川では, 天満川約 $3.5 \mathrm{~km}$ (St. 2-1) , 約5. $5 \mathrm{~km}$ (St. 2-2) ，旧太田 川約7. $5 \mathrm{~km}$ (St. 2-3)，旧太田川約 $9 \mathrm{~km}$ (St. 2-4) の干潟 面において, セジメントトラップは塩分・水温計ととも に設置された(図-1 (a)) . 放水路のSt. 1-2では, 河口 (草津, 測定間隔:1時間) での平均水位を基準として$1.5 \mathrm{~m},-1 \mathrm{~m}$ (B, C ; 低水路) ，0m (A ; タイドプール) に 設置した. 干潟における埋設型セジメントトラップは,

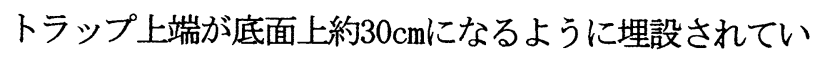
る（図-1(b)）。水位（水深）は海域（St.4; 美能）, 放水路5. $4 \mathrm{~km}$, 草津, 祇園 (国土交通省) の 4 地点で測 定されている. 水温・塩分の設置標高はセジメントト ラップの設置位置に淮じている. セジメントトラップの 設置期間は海域（St. 5) では15日間, 海岸（St. 3) と 放水路（St. 1)，市内派川（St.2）では15日，30日間を 基準としている. 回収された有機泥では, 粒度分布, ク ロロフィル-a, フェオフィチン, POC, PON, POP, SSが 測定されている. さらに，放水路では河口 $0 \mathrm{~km}$ 况 $4.5 \mathrm{~km}$ までの7地点で堆積泥の粒度分布および栄養塩（土粒子 と間隙水に分けて, 窒素, リン, クロロフィル-a, フェ オフィチン, 塩化物量等) が測定されている. 堆積泥の 栄養塩は底質調査法II, SSは沿岸環境マニュアル，水質 はJIS規格に基づいて分析されている.

\section{3. 太田川河口干潟の特性}

広島湾における潮差は年間を通じて約 $4 \mathrm{~m}$ あ, 年変動 成分は $0.5 \mathrm{~m}$ 程度で9〜10月に高く，2〜3月に低くなって おり，この潮差と河川の緩やかな地形勾配によって河道 内に干潟地形が形成されている.

太田川感潮域には洪水を流下させるために，放水路が 構築されており, 河口から約 $10 \mathrm{~km}$ で放水路と市内派川 （放水路分流後の天満川, 本川, 元安川, 京橋川の総 称）に分岐している. 平水時, 流量は, 水門操作により, 概ね放水路へ1割，市内派川に9割が分派されている。 こ のため，放水路と市内派川では河床材料，水質等が異な るために，各々特有の干潟が形成されている.

図一2には，放水路内低水路干潟と市内派川護岸干潟 河床材料の粒度分布および海水の遡上瀕度の比較がされ ている6 ${ }^{6,7)}$. キ口数は調查地点を示しており, 河口から の距離をとっている. 放水路での粒度は $3.2 ， 5.4$, $8.0 \mathrm{~km}$, 地点は低水路干潟, $5.4 \mathrm{~km}$ 地点はタイドプール, 市内派川では護岸干潟での表層泥を対象としている. 海 水の遡上頻度はSt. 1-2 とSt. 2-2に遡上する水塊の塩分か らなる頻度（2003年8～10月上旬の総浸水時間372時間に 対する百分率）が示されている.

\section{（1）放水路干潟}

太田川放水路内には高水敷があり, 高水敷と低水路の 間には石積み護岸が残っている.このため, 高水敷側に はタイドプール, 低水路側には砂干潟等, 良好な干潟地 形が発達している. 平水時には河口から約 $5 \mathrm{~km}$ 上流にあ る干湿帯では干潮時においても, 海水が溜められる状況 （地形, 潮差）となっており, 高水敷に石積み護岸に よってできた窪地には，満潮時になると30psuを超える 海水が流入し，塩性の強いタイドプールが形成されてい る. St. 1-2にあるタイドプールにはシルト分が多く 

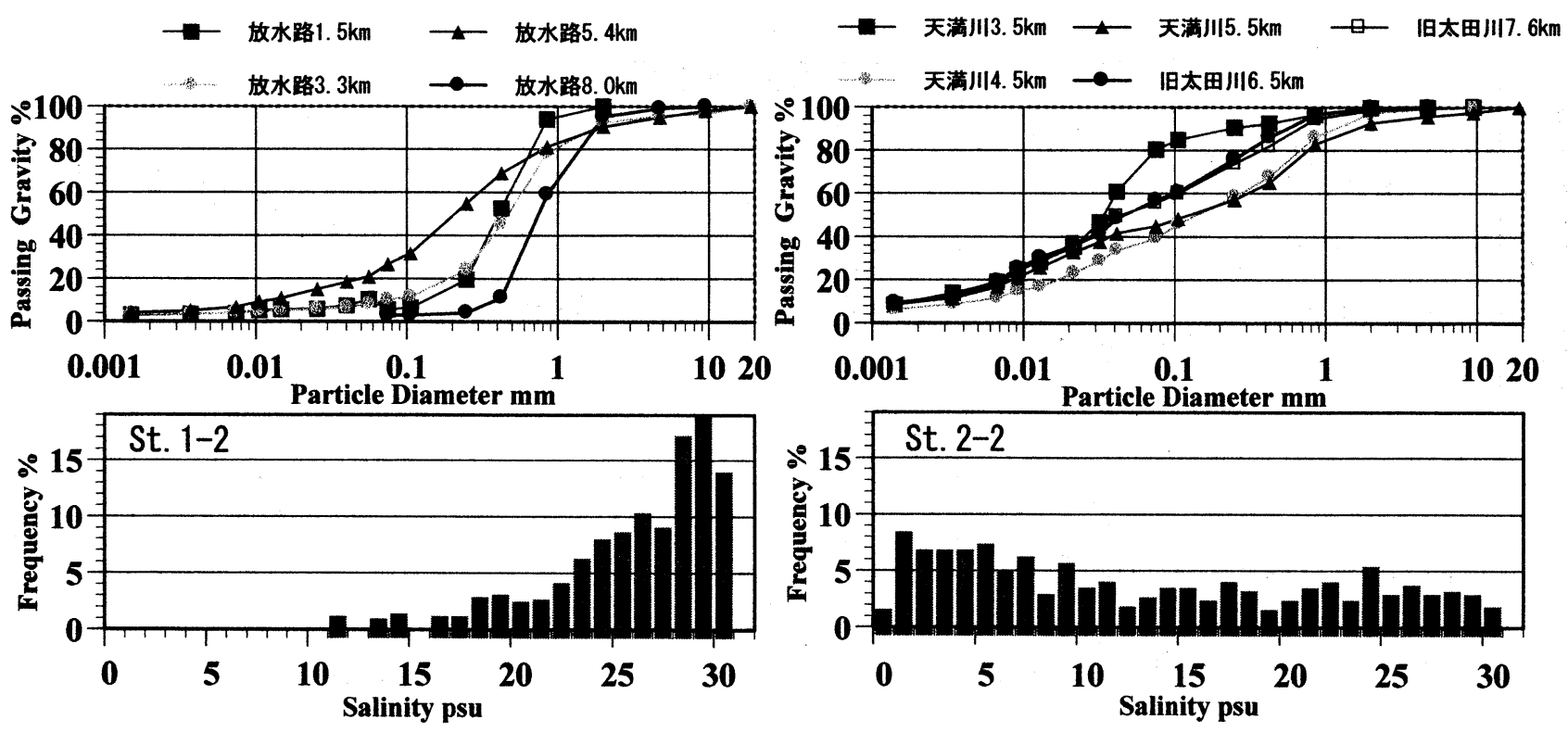

図-2 放水路低水路干潟と市内派川干潟河床材料, 海水遡上頻度の比較

（キロ数は調查地点を示しており，河口からの距離をとっている.）

（図-2粒度分布），タイドプールでは満潮時に海域か ら流入する有機泥を沈降・堆積させることによって干潟 に栄養塩の供給がされ, 生物の摂飭によって栄養塩の循 環が活性化している.さらに，複雑な干潟地形や植物の 繁茂，生物活動によって，放水路内干潟には停滞域が形 成されること等により，粒度の異なる土粒子の分布域が 生じている.

放水路干潟は図-2の粒度分布, 海水の遡上頻度から わかるように, 海域の塩分状態を有する砂干潟に位置つ けられる. 放水路には主に砂分で構成される干潟とシル ト分を $50 \%$ 程度含む干潟の $2 つ$ タイプの干潟が形成して おり, シルト分を多く含む泥は高水敷にできたタイド プール内や低水路護岸の捨石付近に多く堆積している.

\section{(2) 市内派川干潟}

太田川市内派川での断面形状は単断面であるが，護岸 付近には干潟地形が発達して, 干潮時には流水部が5割 程度干出する横断面形状となっている. 河床の表層土に はシルト・粘土が多く含まれており（図-2粒度分布）， 泥干潟に分類される. 海水の遡上は放水路に比較して弱 く(図-2海水遡上頻度), 海水と低塩分水が干満とと もに流出入している. 図一2に示した塩分遡上から，河 口からの距離が同程度 (約 $5.5 \mathrm{~km}$ ) である放水路では淡 水の影響が弱いのに対し，天満川には淡水の影響が強く 現れていることがわかる.

\section{4. 太田川に遡上する水塊の変動特性}

\section{（1）放水路への流入水塊の季節変動特性}

広島湾奥部海域は図-1 (a)に示されるように, 厳島〜
能美島を開口部として，北側に太田川河口，西側に厳島， 東側に呉湾が位置している. 図-3に放水路 $0 \mathrm{~km}$ (河口）, 5. 4km（St. 1-2），8.0km（St. 1-3）での水温・塩分, 放 水路河口（草津）での水位および放水路, 市内派川に分 岐する前の河川流量 (矢口第一) が示されている. 塩分 計は平均潮位面下の位置（干潮時露出）に固定されてお り, 満潮時には海域側の塩分, 干潮に向かって河川水の 塩分を測定している.

図-3から，(1河口域での塩分濃度は広島湾での成層 期6) に低くなっていること，(2)-1放水路上流では小潮期 に塩分の遡上が活発化し，さらに成層が壊れた後の小潮 期には大潮期よりも高塩分, 高水温の水塊が上流まで遡 上していること, (2)-2これとは逆に成層期には河口で塩 分が高くなるのは大潮期であること, (3海域側で塩分が 低くなる6月後半以降に海水温と河口水温が逆転して （河川水温が低くなって）いるが，この状態は2004年以 降も継続的に続いていることがわかる.

\section{（2）夏期の放水路，市内派川への海水の遡上}

図-4には2003年8 10月上旬に放水路と市内派川（天 満川，旧太田川）の河口から上流で測定された塩分の経 時変化が比較されている. St. 2-3では, 塩分とともに河 川流出量（矢口第一）が示されている. 図-4から放水 路と市内派川では海水の遡上距離が異なることがわかる. 天満川 $3.5 \mathrm{~km}$ での満潮時の塩分は, 放水路河口と同程度 の塩分濃度を有しており, $3.5 \mathrm{~km}$ 地点までは満潮時に海 水が淡水との混合が少ない状態で遡上していることから， 天満川にはくさび型の海水遡上（放水路へは混合型）が 推測できる. また, 河口〜中流域で干潮時に塩分の低下 が観測されているときには，上流への海水の遡上が制限 される（放水路で顕著である）ことがわかる．河川流量 


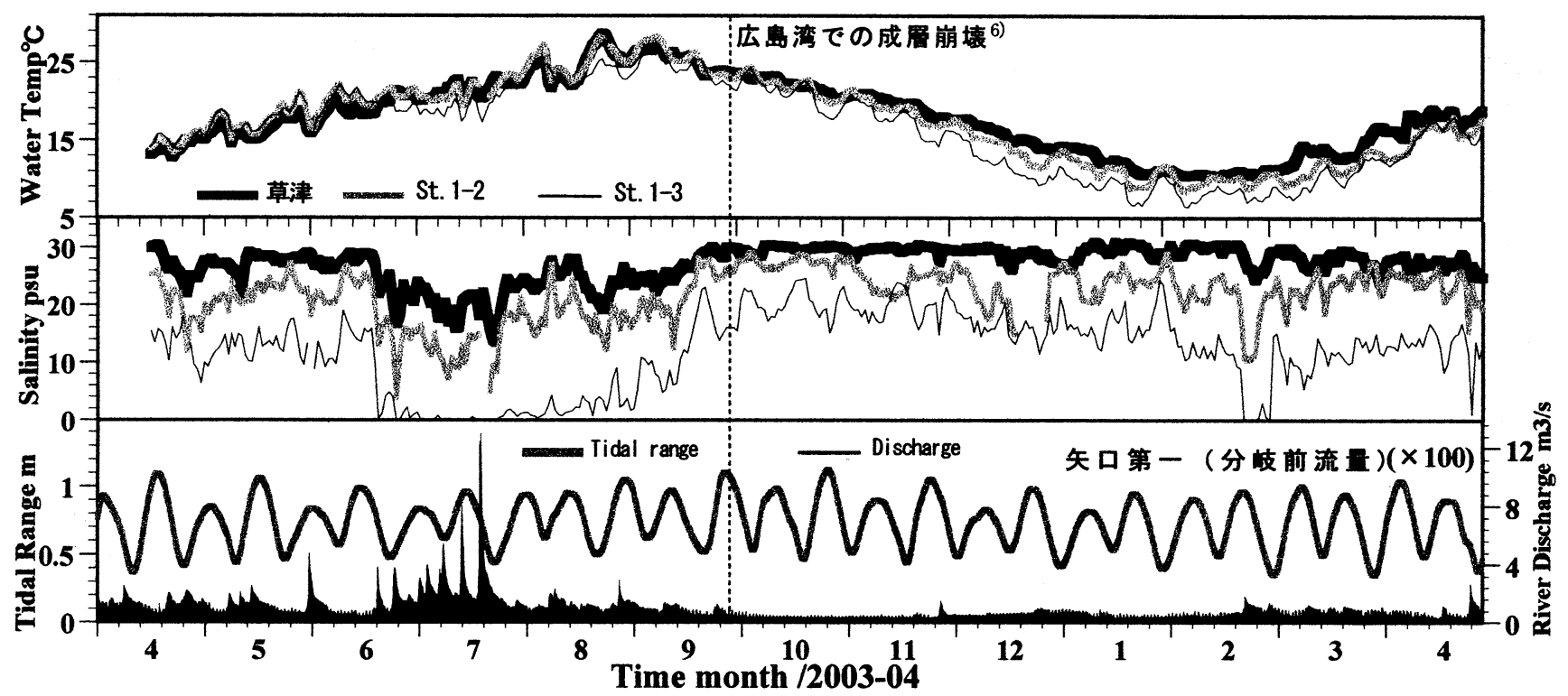

図-3 放水路(St. 1)での水質・塩分 (日平均), 草津での潮差および流量 (分流前流量) の経時変化

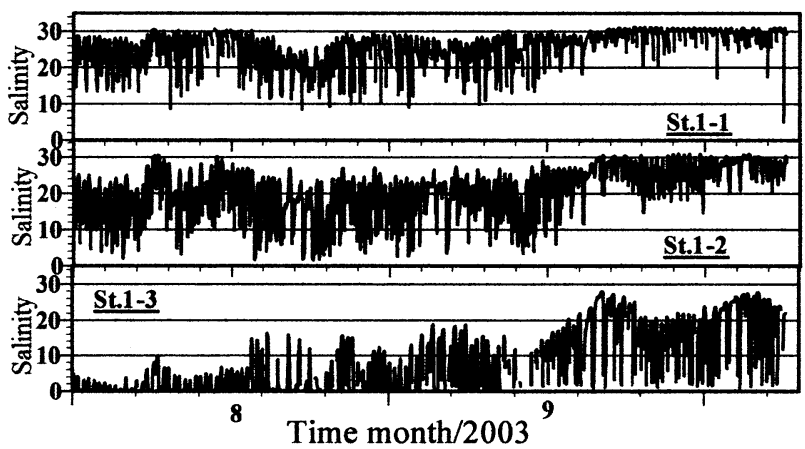

(a) 放水路

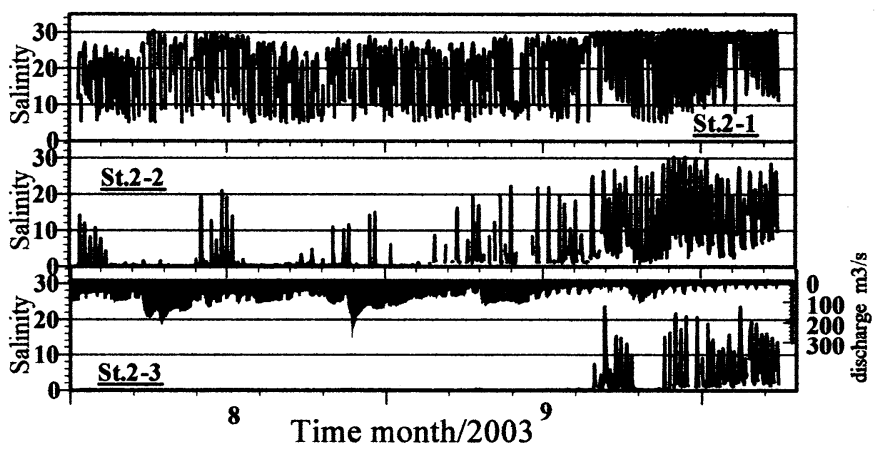

(b) 市内派川

図-4 放水路と市内派川に遡上する海水の状況比較（2003.8.1 10.8）（右下図中央の棒グラフは河川流量）

と塩分低下の相関は低く, 河川流量が塩分の遡上を制限 する直接的な要因であるとは言えないが，河川流量が増 大時に海水遡上が制限される傾向にある.

\section{5. 有機泥の沈降形態と栄䓹塩状態}

\section{(1) 沈降泥の粒度分布}

図-5には(a) 太田川河口周辺域（放水路，市内派川 〜海域)における沈降泥（セジメントトラップによる捕 獲泥）の粒度分布の比較が示されている. 上段には，放 水路, 市内派川 海域（海域は水深 $20 \mathrm{~m}$ 地点でのトラッ プ結果)，下段には, 天満川下流, 宇品, 呉湾沖 (水深 $20 \mathrm{~m}$ と $5 \mathrm{~m}$ ）での比較がされている．観測期間は放水路 (St. 1)，市内派川（St.2），海岸（St. 3) では(a-1)8 月18日〜9月11日（市内派川は9/2開始）と(a-2) 10月 10 〜25日, 海域（St. 5) では(a-1)9月2ー19日と (a-2) 10月 3 30日, 粒径分布はレーザ回折式粒度分布測定装置： SALD-2000J（島津製作所製）によって求められている.
図-5から(1)放水路, 天満川下流, 海岸, 海底での粒 度は類似の分布を有しており, 河川の中，上流域になる に連れて粒径の大きな有機泥が沈降していること, (2)海 域上層で沈降する有機泥は8～9月に大きな粒径粒子を含 んでいるが，10月になると河口域で沈降する有機泥と類 似の粒径分布を有していること，(310月に海底で沈降し た有機泥には粒径の大きい粒子が含まれており，8～9月 期に上層で形成された有機泥の影響が現れていること, (4)-1河川に沈降する有機泥は上流で粒径が大きくなるこ と，(4)-2放水路河口での沈降泥の粒径分布が海域下層で の沈降泥に最も近い粒径分布を有していること， (4)-3海 水の遡上量が多いSt. 1-2では河口からの距離が等しい St. 2-2に沈降する有機泥と比較して海域上層に近い粒径 分布を有していることがわかる.

海域においては，8～9月に一次生産が活発化すること により，植物プランクトン等のデトリタスが上層で捕捉 され，粒径の大きな粒径分布を示している. 海域下層に おいて大粒径の沈降泥が存在しないのは，沈降中の分解 や躍層の存在による7). 

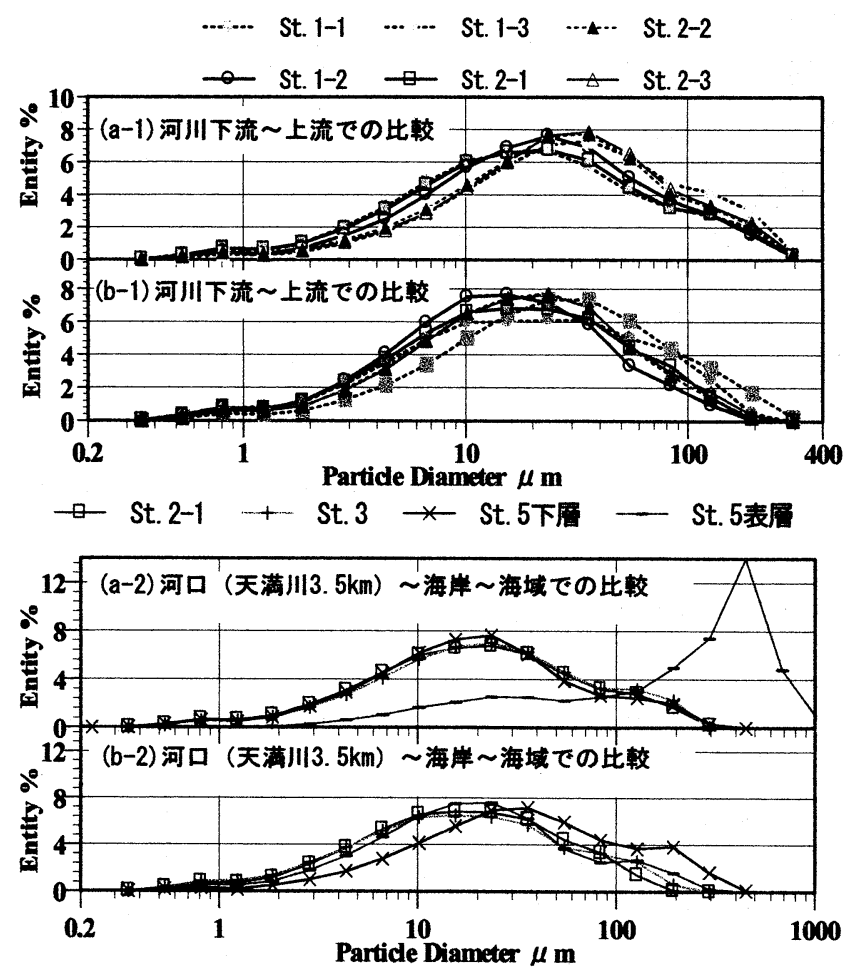

図-5 放水路, 市内派川, 海岸域, 海域での沈降泥の粒度分布 （(a) 2003年9月観測結果，（b) 2003年10月観測結果)

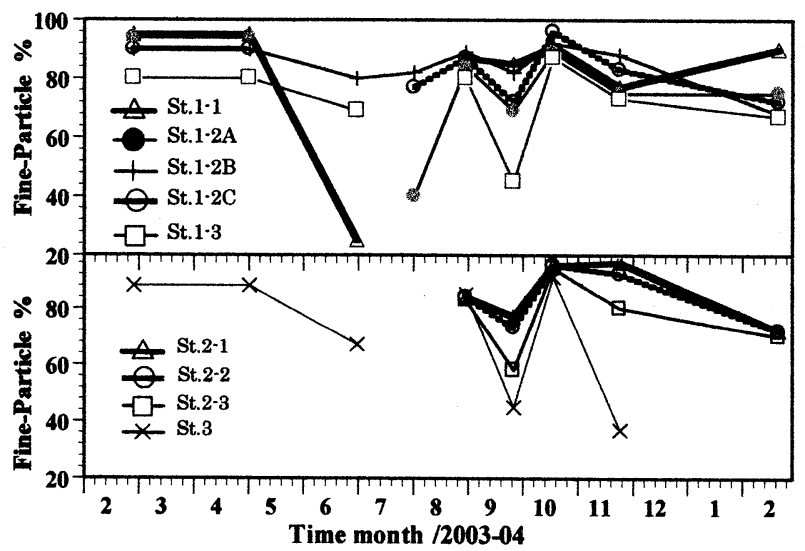

(a) $75 \mu \mathrm{m}$ 以下の粒子の割合

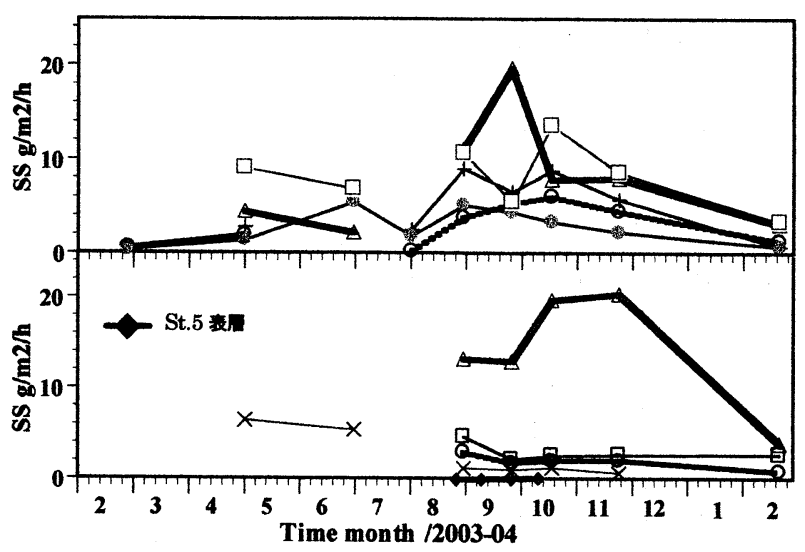

(b) $75 \mu \mathrm{m}$ 以下の粒子の沈降量

図-6 放水路，市内派川，海岸域（宇品），海域での細泥分と 沈降量の季節変動（凡例は(a), (b) で共通)

\section{（2）沈降量の時空間の変動特性}

図-6には，放水路，天満川（旧太田川）の上中下流 で補足された沈降泥の内，(a) 細泥含有率（沈降泥に対

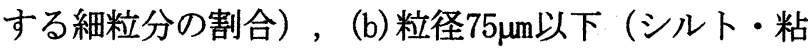
土）の沈降量の季節変動が示されている. 図-6 (a)から, セジメントトラップに沈降する粒子の8割程度が細粒分 である（6〜 7月の含泥率の低下は洪水による砂分の捕 捉による）こと，細粒分の含有率は下〜中流での差は小 さいが，場所毎に構成比に特色があることがわかる．河 口付近で構成比が変化しないのは，主に河川に遡上した 海水に含まれるSSをトラップしているためと考えられる.

図-6（b)より細粒分の沈降量は両河川の下流域で多 くなっており, 最も多いのはSt. 2-1で $15 \mathrm{~g} / \mathrm{m}^{2} / \mathrm{h}$ 以上の沈 降量がある. St. 2-2より上流でのトラップ量はSt. 2-1の 1/3〜1/10, St. 1-2の1/2〜1/5の值を示しており，図-4 との比較により，トラップ量と海水遡上との関連が強い ことが示唆される. St. 5 表層（海域）での沈降量は $0.1 \mathrm{~g} / \mathrm{m}^{2} / \mathrm{h}$ 程度であり, 河口域の $1 / 100$ のーダーでしか ない. St. 3では河口域の $1 / 2$ 程度（平均海面に設置した 場合には $1 / 10$ 程度) であること，放水路（St.1系）では 市内派川（St.2系）に比較して数倍のトラップ量がある ことがわかる.

また, 捕捉量, 細粒分含有率とも夏〜秋期に高く, SS量（75 $\mu \mathrm{m}$ 以下）が多いときには，細粒分の含有率が 高く（正の相関に）なる傾向がある. この傾向は, St. 2-1で顕著に現れている. 海水の遡上のない8～9月上 旬のSt. 2-3（図-4）において約 $6 \mathrm{~g} / \mathrm{m}^{2} / \mathrm{h}$ の沈降量があり （St. 2-1の約1/3），上流域から有機泥の供給もあるこ とがわかる.

\section{（3）沈降泥（トラップによる捕獲泥）の栄筤塩特性}

図-7に放水路，市内派川，海岸域，海域における(a) 栄養塩状態と沈降量（2003年9月と10月POC/PON比; C/N 比の変化率, 沈降泥の比較) および(b) 各水域で細泥分 含有量とC/N比の比較について示した. 図一，7から， (1)-1河川感潮域には $10 \mathrm{~g} / \mathrm{m}^{2} / \mathrm{h}$ 程度の有機泥の沈降があり, この量はSt. 3で沈降する有機泥の2倍程度, St. 5 での沈 降泥の100倍程度になっている（2002年度も同様の結果 7)）こと，(1)-2沈降泥の有機物含有量（SS1g当りのPOC,

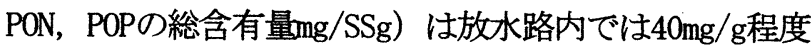
であり，St. 5 表層で大きな值（約 $100 \mathrm{mg} / \mathrm{g}$ 以上，特に9月 に大きい) となっていること，(1)-3 St. 5下層での有機 物含有量は河口域よりも数割程度大きくなっている

(50-80mg/g) こと, (2)-1 C/N比はSt. 5で小さく, 市内 派川で大きい (POCとPONのC/N比から難分解性分と易分 解性分の構成比の情報を知ることができる $\left.{ }^{8)}\right)$ こと， (2)-2 C/N比は細泥分が多くなると大きくなる傾向にある こと, (2)-3 St. 5 表層で粒径の大きい有機泥の沈降が あった一次生産力が高い9月のC/N比は約6（レッド フィールド比；6.625）を示していること，(2)-4 St.5表 


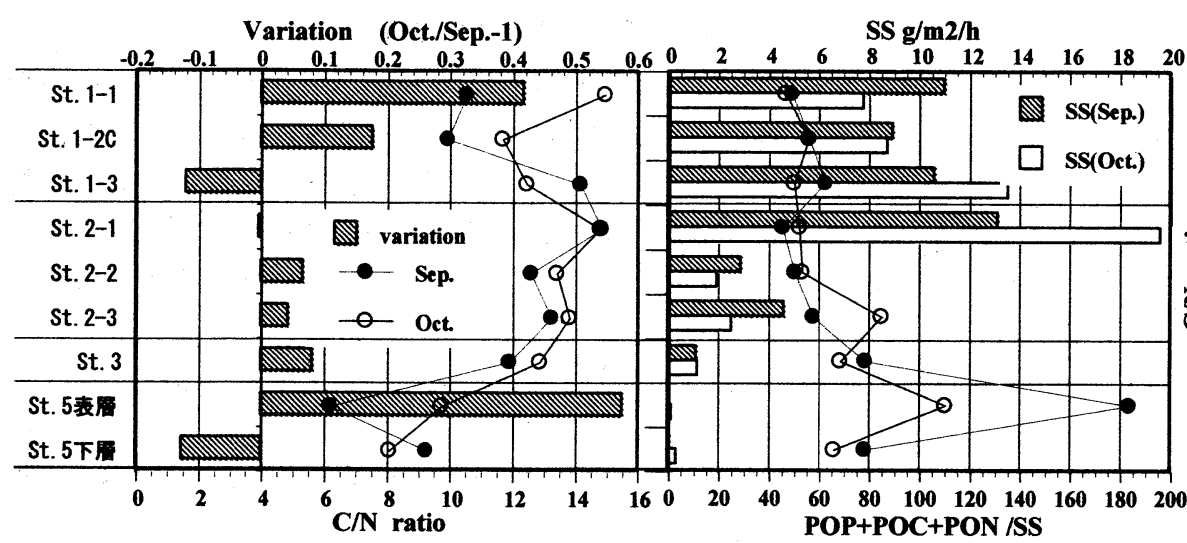

（a）2003年9月と10月沈降泥の栄養塩状態と沈降量の比較

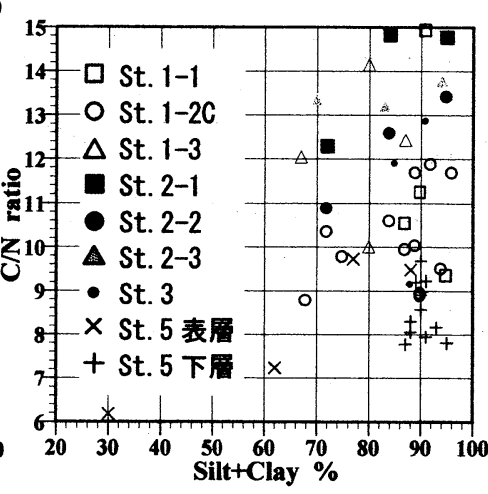

(b) 細粒分含有率とC/N比の比較

図-7 放水路，市内派川，海岸域，海域での栄盖塩状態と沈降量（2003年）

層では10月になるとC/N比が増大し，逆にSt. 5 下層での C/N比が低下していること, (2)-5 St. 5表層でのC/N比の 逆転は，St. 1-1とSt. 1-2でも観測されている（9月のC/N 比は約10）こと，(2)-6市内派川では，C/N比の顕著な逆 転は観測されていないことがわかる.

河川感潮域へは海域から多量の有機泥が運ばれ，河川 内の干潟で沈降していることが予想される.ちなみに, 沈降泥量の年平均值は河口域では $10 \mathrm{~g} / \mathrm{m}^{2} / \mathrm{h}$ 以上, St. 1-2 では約 $7 \mathrm{~g} / \mathrm{m}^{2} / \mathrm{h}$, St. 2-2では約 $2 \mathrm{~g} / \mathrm{m}^{2} / \mathrm{h}$ であった. 河口域 に運ばれ，沈降する有機泥は海域に比較して100倍程度 の沈下量があり, SS1gあたりの有機物量は $1 / 2$ 程度であ ることから，河川感潮域〜河口域では海域の50倍程度の 有機物をトラップしていることになる.

C/N比の比較から，放水路内で沈降する有機泥の多く は沿岸域から輸送されていることが考えられる. 放水路 干潟には, 海域から運ばれた有機泥が多く沈降している のに対し，天満川河口で沈降する有機泥は河口海底付近 に浮遊するへドロを起源とするものが多く含まれている と考えられる. 天満川河口域は上流側への有機泥の供給 源となっていることが示唆され，有機泥濃度は河口域付 近で高くなっていることが考えられる.

\section{6. 結論}

海域～河口域～河川感潮域における有機泥の挙動につ いて検討を行った. 以下に本論文で明らかにした点につ いてまとめる.

（1）太田川感潮域の干潟材料は主に河川上流からの粗粒 分の流送と海水加の細粒分（有機泥）の沈降・再䀣 濁によっていると考えられる. 河川流量の大小により， 海水遡上形態が変化し, 感潮域に形成される干潟材料 が異なる.

（2）太田川放水路における沈降泥の粒径分布は, 河口か ら等距離の市内派川の地点と比較して海域上層に近い
粒径分布を有している. 細粒分（有機泥の堆積量）は, 河口ほど多く, 海水遡上との関連が強いと示唆される. （3）細粒分が多くなると，C/N比は大きくなる傾向にあ るが，C/N比の值は海域と市内派川では大きく異なる.

（4）9月と10月のC/N比の比較から，太田川放水路と市内 派川では, 起源とする有機泥が異なり, 放水路では主 に海域から，市内派川では主に河口海底付近に浮遊す るへドロ起源であると考えられる。

\section{参考文献}

1）清木徹, 伊達悦二, 伊澤博文: 広島湾におけるセディメン ト・トラップ捕集物から推定した水中䝮濁物の沈降フラック ス, 水質污蜀研究 第 8 巻 第 5 号, pp. 304-313, 1985 .

2）村上和男, 鶴谷広一, 入江功:熊本港のシルテーション機構 に関する現地調査およひ数值計算による検討, 第 7 回沿岸域 及び海洋の利用に関するシンポジウム, 1991.

3）鶴谷広一，江口秀二，鷹濱潤:流孔と波による底泥の巻き上 げに関する実験的研究，海岸工学論文集第 35 巻, pp. 357$361,1988$.

4）山下俊彦, 梅林司, 菅沼剛, 斎藤大作, 山崎真一 : 石狩川 の物質輸送特性と河口沿岸域での水質の周年変動, 海岸工学 論文集第 49 巻 (2)，pp. 1011-1015， 2002.

5）山下俊彦, 森田真郷, 杉原幸樹, 斎藤大作, 山崎真一: 石 狩川河川水中の懸濁粒子の海水混合による凝集過程に関する 研究，海岸工学論文集第 49 巻 (2), pp. 1016-1020, 2002.

6）国土交通省中国地方整備局広島港湾空港技術調查事務所 : 平成 $13 \sim 15$ 年度浮泥污濁恰討調查報告書, $2002-4$.

7）日比野忠史, 松本英雄, 西牧均, 村上和男: 干潟浄化能力 の定量的評価手法の提案, 海岸工学論文集第 50 巻 (2), pp. 1071-1075, 2003.

8）小島勲夫, 向井宏, 菊池永祐, 中田喜三郎, 鷲見栄一: 海 底境界層における底質評価に関する研究（その 3 ），第 16 回衛生工学研究会討論会講演論文集, pp. 147-152, 1981.

(2004.9. 30 受付) 